\title{
EFFECT OF CHEMICAL AND ORGANIC FERTILIZER AND AGRICULTURAL DISTANCES ON GROWTH AND YIELD OF TWO LETTUCE (LACTUCA SATIVA L.) VARIETIES GROWN UNDER UNHEATED PLASTIC HOUSE
}

Hussein Jawad Moharrm AL-Bayati Mohammad Talal Abdulsalam AL-Habar

Shamil Y .H. AL-Hamdany

Dept. of Hort. \& Landscape Design, Collage of Agric. \& Forestry, Univ of Mosul, Iraq.

Email:al_bayati_1956@yahoo.com

\begin{abstract}
This experiment was conducted in an unheated plastic house in Horticulture and Landscape design Department, college of Agriculture and Forestry, Mosul University during the winter season of the year 2013-2014 to investigate the possibility of lettuce crop production under protected condition during the winter season, which cannot be grown in the field at this time in Mosul City. Two lettuce cultivars were used Binco and Paris Island, the seeds were planted in 5/9 and transplanted inside the unheated plastic house in 5/11 at two agricultural distances: 30 and $40 \mathrm{~cm}$ and plants were fertilized with two organic fertilizers: Pow hums and Humistar which were applied to the soil as a solution at a rate of $3 \mathrm{gm} \cdot \mathrm{l}^{-1}$ for the two organic fertilizers, the control treatment was fertilized with a chemical fertilizer at the recommended rates. An RCBD factorial experiment with 12 treatments $(2 \times 2 \times 3)$ were used. Results showed that there were no significant differences between the two varieties in most vegetative growth and yield traits while there were a significant superiority of the $40 \mathrm{~cm}$ distance on the $30 \mathrm{~cm}$ distance in head circumference, leaf area, stem weight and mean marketable head weight while there were a significant superiority of the treatment of $30 \mathrm{~cm}$ planting distance in terms of marketable and total yield. It is worth to note that there were no significant differences between the organic fertilization treatments with the normal chemical fertilized plants in terms of vegetative and yield in all vegetative traits mentioned traits expect the mean stem weight.

Key words: Organic fertilization- Planting distance- Lettuce- Plastic house.
\end{abstract}

Received:10/10/2019, Accepted:23/4/2019

\section{INTRODUCTION}

Lettuce (Lactuca sativa L.) which belongs to the family Asteraceae, is one of the important winter leafy vegetables grown in Iraq because of its high nutritional value, which rarely changes or even loses its consumption (Ryder, 1999). There is no documented and up-to-date statistic a survey on the cultivated areas and the production rate in the northern region on this crop, but it is known that there are areas cultivated in the northern and central regions of Iraq. Matlob et, al. (1989) pointed out that the cultivation of this crop in the field in the central region is start in the late summer to give crops during the winter, while the cultivation in the northern region start in late autumn to give the crop during the spring season, so the availability of this crop in the northern region depends on the supply from the 
central region, which fate many problems due to the difficulties of transportation or the lack in production in the central region, which is reflect on increase in the cost of production and high prices in the market so we found that the production under protected or semi-protected means for providing this crop to the consumer during the winter, when it is difficult to be produced in the open field in the northern region during this period. The growth and production of this crop is influenced by many weather and soil factors, in which growth is the result of the combined effect of these factors. Many studies have concluded on the importance of nitrogen fertilization or organic fertilization in improving the productivity and quality of lettuce, since there were is no intensive rooting system, therefore the nutrients must be available in sufficient quantities. The animal fertilizers are added before planting, while the chemical fertilizers are added after initial growth in batches (AlHabar and Al- Saaberi, 2008). Zink and Yamagachi (1962) indicated that most of the growth and absorption of nutrients (70\%) in this crop occurs during the final stages of growth (21 days before harvest), therefore researchers focused on adding chemical and organic fertilizers during this period around the plant. Most of studies focused on the effect of the addition of fertilizers, whether chemical or organic, or the effect of the planting distance factor for this crop when planted in the open field, all of which were important in the growth of this crop, while we did not have any studies in the province of Nineveh under protection, the objective of this study was to investigate the effect of these two factors (the distances plant and the effect organic fertilization compared to the addition of chemical fertilizers on two varieties of lettuce Binco and Paris Island which grown in Nineveh Governorate) to minimize the harmful use of chemical fertilizers on Human health and the environment and to provide this crop locally in the winter instead of bringing from other Governorates.

\section{MATERIALS AND METHODS}

The study was conducted in one of the unheated plastic houses of the Department of Horticulture and Landscape / Faculty of Agriculture and Forestry / University of Mosul to study the impact of three factors, the first factor included the adding of two types of organic fertilizers, (Pow humus and Humistar), to the soil and at the rate of $3 \mathrm{gm} . \mathrm{L}^{-1}$ for both organic fertilizers in addition to the treatment of comparison and table (1) shows the components of these two fertilizers (written on the bags of the types of fertilizer).

Table (1): Shows the components of using organic fertilizers in this experiment:

\begin{tabular}{|lc|lc|}
\hline \multicolumn{2}{|c|}{ Humistar } & \multicolumn{2}{c|}{ Pow humus } \\
\hline Organic extracts $\quad 65 \%$ & Humidity & $14 \%$ \\
& & Potassium humat & $85 \%$ \\
Humic acids & $53 \%$ & $\mathrm{~K}_{2} \mathrm{O}$ & $12 \%$ \\
& & Dry matter & $86 \%$ \\
Folic acids & \multirow{2}{*}{$12 \%$} & $\mathrm{~N}$ & $0.8 \%$ \\
& & & $1 \%$ \\
$\mathrm{~K}_{2} \mathrm{O}$ & $17 \%$ & Others matters & $15 \%$ \\
\hline
\end{tabular}

As installed in each fertilizer pack by the manufacturer. 
Which has been fertilized in adatotation to the control treatment which fertilized with the chemical fertilizer recommended by the Iraqi Ministry of Agriculture at a rate of $240 \mathrm{~kg} \mathrm{~N} \mathrm{ha}^{-1}$ as (urea) and $200 \mathrm{~kg} \mathrm{P} \mathrm{ha}^{-1}$ as (super phosphate) as one batch and $60 \mathrm{~kg} \mathrm{~N}$. ha ${ }^{-1}$ urea second batch (Matlob et, al. 1989), the second factor is two spaces between plants 30 and $40 \mathrm{~cm}$., the previous treatments were carried out on two lettuce varieties of Paris Island produced by Niagara American company and Binco produced by Fitto Spanish company (Third factor) who are followed by Cos or Romaine lettuce group (Ryder, 1999). Thus the study included 12 treatments (2 $\times 3 \times 2$ ) factorial treatment and was applied under Split-Split System in complete randomized block design ( $\mathrm{RCBD})$, the varieties were placed in the main plots and the planting distances in the sub-plots and fertilization treatments in sub-sub-plots with three replicates. The experimental unit area was $2.4 \mathrm{~m}^{2}, 1 \mathrm{~m}$ width and a $2.4 \mathrm{~m}$ long. The seeds were planted in the nursery on 5/9/2013. The seedlings were transferred to the field after two months from the date of planting 5/11/2013. The organic fertilizer were added for both types in three batches, the first was one month after transplanting and repeated three time interval 15 days between them, the chemical fertilizer has been added twice the first included half the nitrogen fertilizer and all P fertilizer white, the second batch included the second half of the nitrogen fertilizer. Drip irrigation pipes were fixed on both sides of the terrace and then the soil was covered with black plastic and then planted with seedlings on both sides of the terrace. Thus the number of plants per experimental unit were 16 plants with $30 \mathrm{~cm}$ spacing and 12 plants $40 \mathrm{~cm}$ spacing. Plants were harvested at the final stage of growth, when the heads become round and before bolting on 25 January 2014 after 80 days of transplanting. The five heads were selected randomly from each experimental unit (15 plants/ treatment) for scientific measurements of the following traits:

1- Growth characteristics:

1. Head length $(\mathrm{cm}) 2$. Head circumference $(\mathrm{cm}) 3$. Leaf area $\left(\mathrm{cm}^{2}\right.$. Plant $\left.{ }^{-1}\right) 4$. Stem length $(\mathrm{cm})$ 5. Stem weight $(\mathrm{g})$ 6. Percentage of dry weight in leaves 7. Chlorophyll percentage in leaves.

2- Yield characteristics:

8. The percentage of involute heads. 9. The average head weight of the marketable heads $(\mathrm{g}) .10$. The marketable and total yield of the heads $\left(\mathrm{kg} / 500 \mathrm{~m}^{2}\right.$ area of the plastic house). The results were statistically able analyzed due to SAS (2001), and the means were compared using Duncan's Multiple rang test under the 0.05 level (Al-Rawi and Khalaf-Allah, 2000).

\section{1- Growth characteristics:}

\section{RESULTS AND DISCUSSION}

The results in tables (2-6) of vegetative growth characteristics such as (head length, head circumference, leaf area, stem length, stem weight) and tables $(7,8)$ for both dry weight of the leaves and chlorophyll in leaves indicate that both Island and Binco varieties were not significantly different in the mentioned characteristics except the significant increase in head length of Binco variety compared with Paris Island. These results are in consistency with Albo- Kalel (2018) who reported that 
there is no significant differences between the two varieties of lettuce Nader and Green Top in the head circumference, the leaf area per plant, stem length, dry weight in the leaves and the chlorophyll in the leaves when studying the lettuce in Bebel Governorate. On the other hand it agrees with the findings of Boroujerdnia and Ansari (2007), Shahein et al. (2015) who found significant differences between the studied lettuce varieties in head length.

For the effect of plant distances, the results indicated the moral superiority of the cultivated plants at a distance of $40 \mathrm{~cm}$ compared to with the distance of $30 \mathrm{~cm}$ in head circumference, leaf area and stem weight. This result is consistence with Moniruzzaman (2006) in head circumference and leaf area, while there is no significant increase the same distance in the rest of the above characteristics.

The effect of the added fertilizers, the results indicated that the organic fertilizers (Humistar and Pow humus) did not differ significantly with the chemical fertilizers in all traits, except the significant increase in stem weight (Table 6) for plants, which fertilized with chemical fertilizer compared with plants fertilized with organic fertilizers. This result is in line with Khazaei et al. (2013) that there is no significant difference between organic fertilizers (Vitamint and Humic) in head length, head circumference, stem length, and leaf dry weight, and with Al-Habar and Al-Bayati (2017) that there is no significant differences between the addition of humic acid and the chemical fertilizer of Paris Island lettuce in head length, the head circumference, stem length, stem weight, leaf area per plant, dry weight in the leaves and the chlorophyll content of the leaves.

The effect of planting distances may be explained by Naseir et al. (2010) who had pointed out that plant spacing or plant density among crops plays a major role in plant growth and production. The efficiency of light absorption by crops requires sufficient leaf

area with even distribution, this increases the competition plants absorbed nutrients among from the soil.

The interaction between varieties $\times$ fertilizer and planting distance $\times$ fertilizer the results showed that there were no significant differences in these interactions in stem length, percentage of dry matter in leaves, and the chlorophyll ratio in the leaves (Tables 5, 7 and 8), but showed significant differences between treatments of varieties $\times$ fertilizer In the head length where the interference of the variety Binco and fertilization with the pow humus gave the highest height of the head, no significant differences were noticed between the factors of this interaction in head circumference table (3). The treatment of the Binco variety and plants with chemical fertilizers gave the highest leaf area per plant, and the $40 \mathrm{~cm}$ spaced plants and fertilized with chemical fertilizer gave the highest leaf area per plant table (4), and interaction treatment of Paris Island variety and plants fertilized by chemical fertilizer and the interaction between $40 \mathrm{~cm}$ spaced plants fertilized with the same fertilizer the highest stem weight Table (6). The results of the interaction between varieties and plant distances showed no significant differences in stem length, percentage of dry matter in leaves, and chlorophyll ratio in leaves $(5,7$ and 8 ), but Binco variety with cultivated plants at a distance of $40 \mathrm{~cm}$ gave the highest length of head and circumference, and leaf area per plant (2, 3 and 4), while the 
treatment of the interference of Paris Island and the cultivated plants at a distance of $40 \mathrm{~cm}$ gave the highest stem weight (Table 6).

In the third interaction between the studied factors, the results of tables $(3,7$ and 8) showed no significant effect of interference coefficients in head circumference, percentage of dry matter in leaves and chlorophyll ratio in leaves, while the interaction treatment between Paris Island variety and plants grown at distance $40 \mathrm{~cm}$ and fertilized with chemical fertilizers gave the highest stem length and stem weight (Tables 5 and 6). The plants of Binco variety with grown at $40 \mathrm{~cm}$ and fertilized with the chemical fertilizer and pow humus gave the highest length of the head and the leaf area per plant respectively (Tables 2 and 4). In general, most of the double and triple interactions coincided with the single effect of each factor and by additives.

Table (2): Effect of variety, plant distance, fertilizer type and their interaction on head length $(\mathrm{cm})$ of lettuce.

\begin{tabular}{|c|c|c|c|c|c|c|}
\hline \multirow[b]{2}{*}{ Varieties } & \multirow[b]{2}{*}{ Distance } & \multicolumn{3}{|c|}{ Fertilizer type } & \multirow{2}{*}{$\begin{array}{c}\text { Variety } \\
\times \\
\text { Distance }\end{array}$} & \multirow{2}{*}{$\begin{array}{c}\text { Mean } \\
\text { Variety }\end{array}$} \\
\hline & & Control & Humistar & $\begin{array}{l}\text { Pow } \\
\text { humus }\end{array}$ & & \\
\hline \multirow{2}{*}{$\begin{array}{l}\text { Paris } \\
\text { Island }\end{array}$} & $30 \mathrm{~cm}$ & $34.55 \mathrm{~cd}$ & $36.10 \mathrm{a}-\mathrm{c}$ & $34.55 \mathrm{~cd}$ & $35.07 \mathrm{~b}$ & \multirow{2}{*}{$\begin{array}{c}34.42 \\
b\end{array}$} \\
\hline & $40 \mathrm{~cm}$ & $35.44 \mathrm{~b}-\mathrm{d}$ & $32.88 \mathrm{~d}$ & $32.99 \mathrm{~d}$ & $33.77 \mathrm{~b}$ & \\
\hline \multirow[t]{2}{*}{ Binco } & $30 \mathrm{~cm}$ & $38.21 \mathrm{ab}$ & $37.21 \mathrm{a}-\mathrm{c}$ & $37.55 \mathrm{ab}$ & $37.66 \mathrm{a}$ & \multirow[t]{2}{*}{$37.92 \mathrm{a}$} \\
\hline & $40 \mathrm{~cm}$ & $38.10 \mathrm{ab}$ & $37.66 \mathrm{ab}$ & $38.77 \mathrm{a}$ & $38.18 \mathrm{a}$ & \\
\hline \multirow{2}{*}{$\begin{array}{l}\text { Variety } \times \\
\text { Fertilizer }\end{array}$} & Paris Island & $34.99 \mathrm{~b}$ & $34.50 \mathrm{~b}$ & $33.77 \mathrm{~b}$ & \multirow{2}{*}{$\begin{array}{c}\text { Mean } \\
\text { Distance }\end{array}$} & \\
\hline & Binco & $38.16 \mathrm{a}$ & $37.44 \mathrm{a}$ & $38.16 \mathrm{a}$ & & \\
\hline \multirow{2}{*}{$\begin{array}{c}\text { Distance } \\
\times \\
\text { Fertilizer }\end{array}$} & $30 \mathrm{~cm}$ & $36.38 \mathrm{a}$ & $36.66 \mathrm{a}$ & $36.05 \mathrm{a}$ & $36.36 \mathrm{a}$ & \\
\hline & $40 \mathrm{~cm}$ & $36.77 \mathrm{a}$ & $35.27 \mathrm{a}$ & $35.88 \mathrm{a}$ & $45.97 \mathrm{a}$ & \\
\hline Mean & ilizer & $36.58 \mathrm{a}$ & $35.96 \mathrm{a}$ & $35.97 \mathrm{a}$ & & \\
\hline
\end{tabular}

The average with same letter for each factor is n.s. according to Duncan's multiple range test under level 0.05 .

Table (3): Effect of variety, plant distance, fertilizer type and their interaction on head circumference $(\mathrm{cm})$ of lettuce.

\begin{tabular}{|c|c|c|c|c|c|c|}
\hline \multirow[b]{2}{*}{ Varieties } & \multirow[b]{2}{*}{ Distance } & \multicolumn{3}{|c|}{ Fertilizer type } & \multirow{2}{*}{$\begin{array}{c}\text { Variety } \\
\times \\
\text { Distance }\end{array}$} & \multirow{2}{*}{$\begin{array}{c}\text { Mean } \\
\text { Variety }\end{array}$} \\
\hline & & Control & Humistar & $\begin{array}{l}\text { Pow } \\
\text { humus }\end{array}$ & & \\
\hline \multirow[t]{2}{*}{ Paris Island } & $30 \mathrm{~cm}$ & $44.99 \mathrm{a}$ & $44.55 \mathrm{a}$ & $41.66 \mathrm{a}$ & $43.73 \mathrm{ab}$ & \multirow[t]{2}{*}{$44.27 \mathrm{a}$} \\
\hline & $40 \mathrm{~cm}$ & $45.99 \mathrm{a}$ & $42.88 \mathrm{a}$ & $45.55 \mathrm{a}$ & $44.81 \mathrm{ab}$ & \\
\hline \multirow[t]{2}{*}{ Binco } & $30 \mathrm{~cm}$ & $42.99 \mathrm{a}$ & $44.21 \mathrm{a}$ & $42.33 \mathrm{a}$ & $43.18 \mathrm{~b}$ & \multirow[t]{2}{*}{$44.62 \mathrm{a}$} \\
\hline & $40 \mathrm{~cm}$ & $46.33 \mathrm{a}$ & $45.44 \mathrm{a}$ & $46.44 \mathrm{a}$ & $46.07 \mathrm{a}$ & \\
\hline \multirow{2}{*}{$\begin{array}{l}\text { Variety } \times \\
\text { Fertilizer }\end{array}$} & Paris Island & $45.49 \mathrm{a}$ & $43.71 \mathrm{a}$ & $43.60 \mathrm{a}$ & \multirow{2}{*}{$\begin{array}{c}\text { Mean } \\
\text { Distance }\end{array}$} & \\
\hline & Binco & $44.66 \mathrm{a}$ & $44.83 \mathrm{a}$ & $44.38 \mathrm{a}$ & & \\
\hline \multirow{2}{*}{$\begin{array}{c}\text { Distance } \times \\
\text { Fertilizer }\end{array}$} & $30 \mathrm{~cm}$ & $43.99 \mathrm{ab}$ & $44.38 \mathrm{ab}$ & $41.99 \mathrm{~b}$ & $43.45 \mathrm{~b}$ & \\
\hline & $40 \mathrm{~cm}$ & $46.16 \mathrm{a}$ & $44.16 \mathrm{ab}$ & $45.99 \mathrm{a}$ & $45.44 \mathrm{a}$ & \\
\hline \multicolumn{2}{|c|}{ Mean Fertilizer } & $45.08 \mathrm{a}$ & $44.27 \quad \mathrm{a}$ & $43.99 \mathrm{a}$ & & \\
\hline
\end{tabular}

The average with same letter for each factor is n.s. according to Duncan's multiple range test under level 0.05 . 
Table (4): Effect of variety, plant distance, fertilizer type and their interaction on leaf area $\left(\mathrm{cm}^{2}\right.$. Plant $\left.{ }^{-1}\right)$ of lettuce.

\begin{tabular}{|c|c|c|c|c|c|c|}
\hline \multirow[b]{2}{*}{ Varieties } & \multirow[b]{2}{*}{ Distance } & \multicolumn{3}{|c|}{ Fertilizer type } & \multirow{2}{*}{$\begin{array}{c}\text { Variety } \\
\times \\
\text { Distance }\end{array}$} & \multirow{2}{*}{$\begin{array}{c}\text { Mean } \\
\text { Variety }\end{array}$} \\
\hline & & Control & Humistar & $\begin{array}{l}\text { Pow } \\
\text { humus }\end{array}$ & & \\
\hline \multirow{2}{*}{$\begin{array}{l}\text { Paris } \\
\text { Island }\end{array}$} & $30 \mathrm{~cm}$ & $7206 \mathrm{bc}$ & 7320 bc & $6290 \mathrm{c}$ & $6939 \mathrm{~b}$ & \multirow[t]{2}{*}{7072 a } \\
\hline & $40 \mathrm{~cm}$ & $7526 \mathrm{bc}$ & $6391 \mathrm{c}$ & $7699 \mathrm{bc}$ & $7205 \mathrm{~b}$ & \\
\hline \multirow[t]{2}{*}{ Binco } & $30 \mathrm{~cm}$ & $6493 \mathrm{bc}$ & $7868 \mathrm{bc}$ & 7488 bc & $7283 \mathrm{~b}$ & \multirow[t]{2}{*}{7806 a } \\
\hline & $40 \mathrm{~cm}$ & $9592 \mathrm{a}$ & $7254 \mathrm{bc}$ & $8139 \mathrm{ab}$ & $8328 \quad \mathrm{a}$ & \\
\hline \multirow[t]{2}{*}{$\begin{array}{l}\text { Variety } \times \\
\text { Fertilizer }\end{array}$} & $\begin{array}{l}\text { Paris } \\
\text { Island }\end{array}$ & $7366 \mathrm{ab}$ & $6855 \mathrm{~b}$ & $6994 \mathrm{ab}$ & \multirow[t]{2}{*}{$\begin{array}{c}\text { Mean } \\
\text { Distance }\end{array}$} & \\
\hline & Binco & $8042 \mathrm{a}$ & $7561 \mathrm{ab}$ & $7814 \mathrm{ab}$ & & \\
\hline \multirow{2}{*}{$\begin{array}{l}\text { Distance } \\
\times \\
\text { Fertilizer } \\
\end{array}$} & $30 \mathrm{~cm}$ & $6850 \mathrm{~b}$ & $7594 \mathrm{ab}$ & $6889 \mathrm{~b}$ & $7111 \mathrm{~b}$ & \\
\hline & $40 \mathrm{~cm}$ & 8559 a & $6822 \mathrm{~b}$ & $7919 \mathrm{ab}$ & $7767 \quad a$ & \\
\hline Mean & zer & $7704 \mathrm{a}$ & $7208 \mathrm{a}$ & 7404 & & \\
\hline
\end{tabular}

The average with same letter for each factor is n.s. according to Duncan's multiple range test under level 0.05 .

Table (5): Effect of variety, plant distance, fertilizer type and their interaction on stem length $(\mathrm{cm})$ for lettuce.

\begin{tabular}{|c|c|c|c|c|c|c|}
\hline \multirow[b]{2}{*}{ Varieties } & \multirow[b]{2}{*}{ Distance } & \multicolumn{3}{|c|}{ Fertilizer type } & \multirow{2}{*}{$\begin{array}{c}\text { Variety } \\
\times \\
\text { Distance }\end{array}$} & \multirow{2}{*}{$\begin{array}{c}\text { Mean } \\
\text { Variety }\end{array}$} \\
\hline & & Control & Humistar & $\begin{array}{l}\text { Pow } \\
\text { humus }\end{array}$ & & \\
\hline \multirow{2}{*}{$\begin{array}{l}\text { Paris } \\
\text { Island }\end{array}$} & $30 \mathrm{~cm}$ & $8.99 \mathrm{ab}$ & $9.16 \mathrm{ab}$ & $8.05 \mathrm{~b}$ & $8.73 \mathrm{a}$ & \multirow[t]{2}{*}{$8.82 \mathrm{a}$} \\
\hline & $40 \mathrm{~cm}$ & $9.72 \mathrm{a}$ & $8.22 \mathrm{ab}$ & $8.77 \mathrm{ab}$ & $8.90 \mathrm{a}$ & \\
\hline \multirow[t]{2}{*}{ Binco } & $30 \mathrm{~cm}$ & $9.49 \mathrm{ab}$ & $9.10 \mathrm{ab}$ & $8.83 \mathrm{ab}$ & $9.14 \quad \mathrm{a}$ & \multirow[t]{2}{*}{$9.20 \mathrm{a}$} \\
\hline & $40 \mathrm{~cm}$ & $9.24 \mathrm{ab}$ & $8.99 \mathrm{ab}$ & $9.55 \mathrm{ab}$ & $9.26 \mathrm{a}$ & \\
\hline \multirow[t]{2}{*}{$\begin{array}{l}\text { Variety } \times \\
\text { Fertilizer }\end{array}$} & $\begin{array}{l}\text { Paris } \\
\text { Island }\end{array}$ & $9.35 \mathrm{a}$ & $8.69 \mathrm{a}$ & $8.41 \mathrm{a}$ & \multirow[t]{2}{*}{$\begin{array}{c}\text { Mean } \\
\text { Distance }\end{array}$} & \\
\hline & Binco & $9.37 \mathrm{a}$ & $9.05 \mathrm{a}$ & $9.19 \mathrm{a}$ & & \\
\hline \multirow{2}{*}{$\begin{array}{l}\text { Distance } \\
\times \\
\text { Fertilizer }\end{array}$} & $30 \mathrm{~cm}$ & $9.24 \mathrm{a}$ & $9.13 \mathrm{a}$ & $8.44 \quad \mathrm{a}$ & $8.94 \quad \mathrm{a}$ & \\
\hline & $40 \mathrm{~cm}$ & $9.48 \mathrm{a}$ & $8.60 \mathrm{a}$ & $9.16 \mathrm{a}$ & $9.08 \mathrm{a}$ & \\
\hline \multicolumn{2}{|c|}{ Mean Fertilizer } & $9.36 \mathrm{a}$ & $8.87 \mathrm{a}$ & $8.80 \mathrm{a}$ & & \\
\hline
\end{tabular}

The average with same letter for each factor is n.s. according to Duncan's multiple range test under level 0.05 . 
Table (6): Effect of variety, plant distance, fertilizer type and their interaction on stem weight (gm) for lettuce.

\begin{tabular}{|c|c|c|c|c|c|c|}
\hline \multirow[b]{2}{*}{ Varieties } & \multirow[b]{2}{*}{ Distance } & \multicolumn{3}{|c|}{ Fertilizer type } & \multirow{2}{*}{$\begin{array}{c}\text { Variety } \\
\times \\
\text { Distance }\end{array}$} & \multirow{2}{*}{$\begin{array}{c}\text { Mean } \\
\text { Variety }\end{array}$} \\
\hline & & Control & Humistar & $\begin{array}{c}\text { Pow } \\
\text { humus }\end{array}$ & & \\
\hline \multirow[t]{2}{*}{$\begin{array}{l}\text { Paris } \\
\text { Island }\end{array}$} & $30 \mathrm{~cm}$ & $\begin{array}{c}83.58 \\
\text { ab }\end{array}$ & $82.56 \mathrm{ab}$ & $68.89 \mathrm{bc}$ & $78.34 \mathrm{a}$ & \multirow[t]{2}{*}{$81.34 \mathrm{a}$} \\
\hline & $40 \mathrm{~cm}$ & $96.71 \mathrm{a}$ & $72.92 \mathrm{bc}$ & $83.40 \mathrm{ab}$ & $84.34 \mathrm{a}$ & \\
\hline \multirow[t]{2}{*}{ Binco } & $30 \mathrm{~cm}$ & $60.72 \mathrm{c}$ & $60.65 \mathrm{c}$ & $55.36 \mathrm{c}$ & $58.91 \mathrm{~b}$ & \multirow[t]{2}{*}{$63.37 \mathrm{a}$} \\
\hline & $40 \mathrm{~cm}$ & $\begin{array}{c}74.24 \\
\text { bc }\end{array}$ & $57.83 \mathrm{c}$ & $71.41 \mathrm{bc}$ & $67.82 \mathrm{~b}$ & \\
\hline \multirow[t]{2}{*}{$\begin{array}{l}\text { Variety } \times \\
\text { Fertilizer }\end{array}$} & $\begin{array}{l}\text { Paris } \\
\text { Island }\end{array}$ & $90.14 \mathrm{a}$ & $77.74 \mathrm{ab}$ & $76.15 \mathrm{bc}$ & \multirow[t]{2}{*}{$\begin{array}{c}\text { Mean } \\
\text { Distance }\end{array}$} & \\
\hline & Binco & $\begin{array}{c}67.48 \text { b- } \\
\text { d }\end{array}$ & $59.24 \mathrm{~d}$ & $63.38 \mathrm{~cd}$ & & \\
\hline \multirow{2}{*}{$\begin{array}{c}\text { Distance } \\
\times \\
\text { Fertilizer }\end{array}$} & $30 \mathrm{~cm}$ & $\begin{array}{c}72.15 \\
\mathrm{bc}\end{array}$ & $71.60 \mathrm{bc}$ & $62.12 \mathrm{c}$ & $68.63 \mathrm{~b}$ & \\
\hline & $40 \mathrm{~cm}$ & $85.47 \mathrm{a}$ & $65.37 \mathrm{bc}$ & $77.40 \mathrm{ab}$ & $76.08 \mathrm{a}$ & \\
\hline Mean & lizer & $78.81 \mathrm{a}$ & $68.49 \mathrm{~b}$ & $69.76 \mathrm{~b}$ & & \\
\hline
\end{tabular}

The average with same letter for each factor is n.s. according to Duncan s multiple range test under level 0.05 .

Table (7): Effect of variety, plant distance, fertilizer type and their interaction on leaves dry matter $\%$ for lettuce.

\begin{tabular}{|c|c|c|c|c|c|c|}
\hline \multirow[b]{2}{*}{ Varieties } & \multirow[b]{2}{*}{ Distance } & \multicolumn{3}{|c|}{ Fertilizer type } & \multirow{2}{*}{$\begin{array}{c}\text { Variety } \\
\times \\
\text { Distance }\end{array}$} & \multirow{2}{*}{$\begin{array}{c}\text { Mean } \\
\text { Variety }\end{array}$} \\
\hline & & Control & Humistar & $\begin{array}{c}\text { Pow } \\
\text { humus }\end{array}$ & & \\
\hline \multirow{2}{*}{$\begin{array}{l}\text { Paris } \\
\text { Island }\end{array}$} & $30 \mathrm{~cm}$ & $5.43 \mathrm{a}$ & $5.24 \mathrm{a}$ & $5.42 \mathrm{a}$ & $5.36 \mathrm{a}$ & \multirow[t]{2}{*}{$5.31 \mathrm{a}$} \\
\hline & $40 \mathrm{~cm}$ & $5.27 \mathrm{a}$ & $5.37 \mathrm{a}$ & $5.15 \mathrm{a}$ & $5.26 \mathrm{a}$ & \\
\hline \multirow[t]{2}{*}{ Binco } & $30 \mathrm{~cm}$ & $5.15 \mathrm{a}$ & $5.71 \mathrm{a}$ & $5.13 \mathrm{a}$ & $5.33 \mathrm{a}$ & \multirow[t]{2}{*}{$5.26 \mathrm{a}$} \\
\hline & $40 \mathrm{~cm}$ & $5.46 \mathrm{a}$ & $4.93 \mathrm{a}$ & $5.16 \mathrm{a}$ & $5.18 \mathrm{a}$ & \\
\hline \multirow{2}{*}{$\begin{array}{l}\text { Variety } \times \\
\text { Fertilizer }\end{array}$} & Paris Island & $5.35 \mathrm{a}$ & $5.30 \mathrm{a}$ & $5.28 \mathrm{a}$ & \multirow{2}{*}{$\begin{array}{c}\text { Mean } \\
\text { Distanc } \\
\mathrm{e} \\
\end{array}$} & \\
\hline & Binco & $5.31 \mathrm{a}$ & $5.32 \mathrm{a}$ & $5.14 \mathrm{a}$ & & \\
\hline \multirow{2}{*}{$\begin{array}{c}\text { Distance } \times \\
\text { Fertilizer } \\
\end{array}$} & $30 \mathrm{~cm}$ & $5.29 \mathrm{a}$ & $5.47 \mathrm{a}$ & $5.28 \mathrm{a}$ & $5.35 \mathrm{a}$ & \\
\hline & $40 \mathrm{~cm}$ & $5.36 \mathrm{a}$ & $5.15 \mathrm{a}$ & $5.15 \mathrm{a}$ & $5.22 \mathrm{a}$ & \\
\hline \multicolumn{2}{|c|}{ Mean Fertilizer } & $5.33 \mathrm{a}$ & 5.31 & 5.21 & & \\
\hline
\end{tabular}

The average with same letter for each factor is n.s. according to Duncan's multiple range test under level 0.05 . 
Table (8): Effect of variety, plant distance, fertilizer type and their interaction on chlorophyll in leaves (spad) for lettuce.

\begin{tabular}{|c|c|c|c|c|c|c|}
\hline \multirow[b]{2}{*}{ Varieties } & \multirow[b]{2}{*}{ Distance } & \multicolumn{3}{|c|}{ Fertilizer type } & \multirow{2}{*}{$\begin{array}{c}\text { Variety } \\
\times \\
\text { Distance }\end{array}$} & \multirow{2}{*}{$\begin{array}{c}\text { Mean } \\
\text { Variety }\end{array}$} \\
\hline & & Control & Humistar & $\begin{array}{c}\text { Pow } \\
\text { humus }\end{array}$ & & \\
\hline \multirow{2}{*}{$\begin{array}{l}\text { Paris } \\
\text { Island }\end{array}$} & $30 \mathrm{~cm}$ & $12.39 \mathrm{a}$ & $11.03 \mathrm{a}$ & $11.77 \mathrm{a}$ & $11.73 \mathrm{a}$ & \multirow[t]{2}{*}{$12.17 \mathrm{a}$} \\
\hline & $40 \mathrm{~cm}$ & $11.54 \mathrm{a}$ & $13.39 \mathrm{a}$ & $12.92 \mathrm{a}$ & $12.62 \mathrm{a}$ & \\
\hline \multirow[t]{2}{*}{ Binco } & $30 \mathrm{~cm}$ & $12.40 \mathrm{a}$ & $11.92 \mathrm{a}$ & $13.37 \mathrm{a}$ & $12.56 \mathrm{a}$ & \multirow[t]{2}{*}{$12.53 \mathrm{a}$} \\
\hline & $40 \mathrm{~cm}$ & $12.62 \mathrm{a}$ & $12.55 \mathrm{a}$ & $12.35 \mathrm{a}$ & $12.51 \mathrm{a}$ & \\
\hline \multirow{2}{*}{$\begin{array}{l}\text { Variety } \times \\
\text { Fertilizer }\end{array}$} & Paris Island & $11.96 \mathrm{a}$ & $12.21 \mathrm{a}$ & $12.34 \mathrm{a}$ & \multirow{2}{*}{$\begin{array}{c}\text { Mean } \\
\text { Distanc } \\
\mathrm{e} \\
\end{array}$} & \\
\hline & Binco & $12.51 \mathrm{a}$ & $12.24 \mathrm{a}$ & $12.86 \mathrm{a}$ & & \\
\hline \multirow{2}{*}{$\begin{array}{c}\text { Distance } \times \\
\text { Fertilizer }\end{array}$} & $30 \mathrm{~cm}$ & $12.39 \mathrm{a}$ & $11.47 \mathrm{a}$ & $12.57 \mathrm{a}$ & $12.15 \mathrm{a}$ & \\
\hline & $40 \mathrm{~cm}$ & $12.08 \mathrm{a}$ & $12.97 \mathrm{a}$ & $12.63 \mathrm{a}$ & $12.56 \mathrm{a}$ & \\
\hline \multicolumn{2}{|c|}{ Mean Fertilizer } & $12.24 \mathrm{a}$ & $12.22 \mathrm{a}$ & $12.60 \mathrm{a}$ & & \\
\hline
\end{tabular}

The average with same letter for each factor is n.s. according to Duncan's multiple range test under level 0.05 .

\section{2- Yield characteristics:}

Results of tables $(9,10$ and 12) showed no significant differences between Paris Island and Binco in the percentage of wrapped header, head weight, and total yield, while Binco variety were significantly superior in marketable yield with an increase of $32.1 \%$ (Table 11). This difference may be explained by the significant decline in the plants of Paris Island, which is grown at $30 \mathrm{~cm}$ on the Binco plants and grown at both distances in the ratio of the coated heads (note the dual interference) (Table 9).

The effect of planting distances there was no significant difference observed between the planting distances 30 and $40 \mathrm{~cm}$ in the percentage of heads involute table (9), but the

planting distance $40 \mathrm{~cm}$ was significantly superior in the average of marketable head weight table (10) with an increase of $9.06 \%$, while cultivated plants at a distance of $30 \mathrm{~cm}$ gave the highest total and marketing yield with an increase of 18.79 and $15.81 \%$, respectively (Tables 11 and 12). This result is consistent with Hasan et al. (2017) in superiority of planting distance of 30 and $25 \mathrm{~cm}$ between the lettuce plants in the total yield, marketing of the heads.

While the effect of the added fertilizers, results indicated that the plants with organic fertilizers Humistar and Pow humus did not significantly differ with the chemical fertilizer plants for all characteristics of yield (percentage of the involute heads and the average of head weight and the total, marketable yield of heads) Tables $(9,10,11$ and 12). This result is in line with what was mentioned by the AlHabar and Al-Bayati (2017) in the absence of significant differences between the addition of humic acid and the chemical fertilizer of the lettuce Paris Island variety in the percentage of covered heads and average head weight of marketing and the total and marketing yield of the heads.

The interaction between varieties and fertilization and between planting distances and fertilization, results indicated that there was no significant effect 
between the coefficients of these two interactions in the percentage of the involute heads, while the Binco variety which were planted at $40 \mathrm{~cm}$ higher than those of Paris Island plants which were planted at $30 \mathrm{~cm}$ only in this trait table (9).

The results of the interaction between varieties and fertilization in total and marketable yield indicate that the Binco variety fertilized with chemical fertilizers gave the highest mean of marketable head weight and the total and marketable yield of the heads, the differences were not significant with the plants of the same variety and fertilizers with organic fertilizers, but significantly different with Paris Island plants fertilized with chemical and organic fertilizers Tables (10, 11 and 12).

The interaction between distances and fertilization results indicated that the plants grown at $40 \mathrm{~cm}$ and fertilized with chemical fertilizer gave the highest average of marketable head weight, and significantly different with all treatments table (10), while the plants with $30 \mathrm{~cm}$ spaces and fertilized with Humistar fertilizer gave the highest marketable and total yield of heads, and no significant difference with the plants planted at the same distance and fertilized with chemical and organic fertilizer, Pow humus, but significantly different with all plants which were planted at $40 \mathrm{~cm}$ and fertilized with organic fertilizer Humistar and Pow humus in the marketable and total yield of the heads, except these planted at $40 \mathrm{~cm}$ and fertilized with chemical fertilizer in marketable yield only tables $(11,12)$.

The interaction between varieties and distances results indicated that the plants of Binco variety planted at $40 \mathrm{~cm}$ gave the significant higher mean of marketable head weight, but the plants of the same variety planted at $30 \mathrm{~cm}$ gave a higher marketable and total yield of heads.

The third interaction between the studied factors, the results showed that the plants of the Binco variety planted at $40 \mathrm{~cm}$ and fertilized with Pow humus and the plants of Paris Island, planted on the same distance fertilized with Humistar gave the highest percentage of involute heads which reached 100\%, and significantly different only with the Paris Island plants planted at $30 \mathrm{~cm}$ and fertilized with Pow humus (Table 9). The average weight of marketable heads, the Binco plants which spaced at $40 \mathrm{~cm}$ and fertilized with chemical fertilizers gave the highest average head weight, and did not differ significantly with the plants of the same cultivar and planted on the same distance and the Humistar fertilizer, but significantly differ with all treatments, table (10). The results showed that the Binco plants, planted at $30 \mathrm{~cm}$ and fertilized with Humistar gave the highest total and marketable yield of heads, which reached 2665.00 and $2326.40 \mathrm{~kg}$. in $500 \mathrm{~m}^{2}$ Tables (11 and 12). These results indicated that in general, most of the bilateral and triple interactions of the previous factors have been correlated with the single effect of each factor. 
Table (9): Effect of variety, plant distance, fertilizer type and their interaction on the percentage of wrapped heads of lettuce.

\begin{tabular}{|c|c|c|c|c|c|c|}
\hline \multirow[b]{2}{*}{ Varieties } & \multirow[b]{2}{*}{ Distance } & \multicolumn{3}{|c|}{ Fertilizer type } & \multirow{2}{*}{$\begin{array}{c}\text { Variety } \\
\times \\
\text { Distance }\end{array}$} & \multirow{2}{*}{$\begin{array}{c}\text { Mean } \\
\text { Variety }\end{array}$} \\
\hline & & Control & Humistar & $\begin{array}{l}\text { Pow } \\
\text { humus }\end{array}$ & & \\
\hline \multirow[t]{2}{*}{$\begin{array}{l}\text { Paris } \\
\text { Island }\end{array}$} & $30 \mathrm{~cm}$ & $\begin{array}{c}90.77 \\
\mathrm{ab}\end{array}$ & $86.16 \mathrm{ab}$ & $85.13 \mathrm{~b}$ & $87.35 \mathrm{~b}$ & \multirow[t]{2}{*}{$90.80 \mathrm{a}$} \\
\hline & $40 \mathrm{~cm}$ & $\begin{array}{c}88.88 \\
\mathrm{ab}\end{array}$ & $100.00 \mathrm{a}$ & $93.88 \mathrm{ab}$ & $\begin{array}{c}94.25 \\
\mathrm{ab}\end{array}$ & \\
\hline \multirow[t]{2}{*}{ Binco } & $30 \mathrm{~cm}$ & $\begin{array}{c}95.83 \\
a b\end{array}$ & $93.61 \mathrm{ab}$ & $97.91 \mathrm{ab}$ & $95.78 \mathrm{a}$ & \multirow[t]{2}{*}{$96.88 \mathrm{a}$} \\
\hline & $40 \mathrm{~cm}$ & $\begin{array}{c}96.96 \\
\mathrm{ab}\end{array}$ & $96.96 \mathrm{ab}$ & $\begin{array}{l}100.00 \\
\mathrm{a}\end{array}$ & $97.97 \mathrm{a}$ & \\
\hline \multirow[t]{2}{*}{$\begin{array}{l}\text { Variety } \times \\
\text { Fertilizer }\end{array}$} & $\begin{array}{l}\text { Paris } \\
\text { Island }\end{array}$ & $89.82 \mathrm{a}$ & $93.08 \mathrm{a}$ & $89.51 \mathrm{a}$ & \multirow[t]{2}{*}{$\begin{array}{c}\text { Mean } \\
\text { Distance }\end{array}$} & \\
\hline & Binco & $96.40 \mathrm{a}$ & $95.28 \mathrm{a}$ & $98.95 \mathrm{a}$ & & \\
\hline \multirow{2}{*}{$\begin{array}{c}\text { Distance } \\
\times \\
\text { Fertilizer }\end{array}$} & $30 \mathrm{~cm}$ & $93.30 \mathrm{a}$ & $89.88 \mathrm{a}$ & $91.52 \mathrm{a}$ & $91.57 \mathrm{a}$ & \\
\hline & $40 \mathrm{~cm}$ & $92.92 \mathrm{a}$ & $98.48 \mathrm{a}$ & $96.94 \mathrm{a}$ & $96.11 \mathrm{a}$ & \\
\hline \multicolumn{2}{|c|}{ Mean Fertilizer } & $93.11 \mathrm{a}$ & $94.18 \mathrm{a}$ & $94.23 \mathrm{a}$ & & \\
\hline
\end{tabular}

The average with same letter for each factor is n.s. according to Duncan's multiple range test under level 0.05 .

Table (10): Effect of variety, plant distance and fertilizer type and their interaction on mean of marketable head weight $(\mathrm{kg})$ of lettuce.

\begin{tabular}{|c|c|c|c|c|c|c|}
\hline \multirow[b]{2}{*}{ Varieties } & \multirow[b]{2}{*}{ Distance } & \multicolumn{3}{|c|}{ Fertilizer type } & \multirow{2}{*}{$\begin{array}{c}\text { Variety } \\
\times \\
\text { Distance }\end{array}$} & \multirow{2}{*}{$\begin{array}{c}\text { Mean } \\
\text { Variety }\end{array}$} \\
\hline & & Control & Humistar & $\begin{array}{l}\text { Pow } \\
\text { humus }\end{array}$ & & \\
\hline \multirow{2}{*}{$\begin{array}{l}\text { Paris } \\
\text { Island }\end{array}$} & $30 \mathrm{~cm}$ & $644 d-f$ & 696 c-e & 597 ef & $645 c$ & \multirow[t]{2}{*}{$659 a$} \\
\hline & $40 \mathrm{~cm}$ & $723 \mathrm{~cd}$ & $587 \mathrm{f}$ & $710 \mathrm{~cd}$ & $673 \mathrm{c}$ & \\
\hline \multirow[t]{2}{*}{ Binco } & $30 \mathrm{~cm}$ & $741 \mathrm{~b}-\mathrm{d}$ & 762 bc & $732 \mathrm{~cd}$ & $745 \mathrm{~b}$ & \multirow[t]{2}{*}{794 a } \\
\hline & $40 \mathrm{~cm}$ & 909 a & $836 \mathrm{ab}$ & 784 & 843 a & \\
\hline \multirow[t]{2}{*}{$\begin{array}{l}\text { Variety } \times \\
\text { Fertilizer }\end{array}$} & $\begin{array}{l}\text { Paris } \\
\text { Island }\end{array}$ & $684 \mathrm{~b}$ & $641 b$ & 653 & \multirow[t]{2}{*}{$\begin{array}{c}\text { Mean } \\
\text { Distance }\end{array}$} & \\
\hline & Binco & $825 \mathrm{a}$ & 799 a & 758 & & \\
\hline \multirow{2}{*}{$\begin{array}{c}\text { Distance } \\
\times \\
\text { Fertilizer }\end{array}$} & $30 \mathrm{~cm}$ & 692 bc & 729 bc & 665 & $695 \mathrm{~b}$ & \\
\hline & $40 \mathrm{~cm}$ & 816 a & 712 bc & 747 & 758 a & \\
\hline Mean & izer & 754 a & $720 \quad \mathrm{a}$ & 706 & & \\
\hline
\end{tabular}

The average with same letter for each factor is n.s. according to Duncan's multiple range test under level 0.05 . 
Table (11): Effect of variety, plant distance and fertilizer type and their interaction on marketable yield $\left(\mathrm{kg} .500 \mathrm{~m}^{2}\right)$ of lettuce.

\begin{tabular}{|c|c|c|c|c|c|c|}
\hline \multirow[b]{2}{*}{ Varieties } & \multirow[b]{2}{*}{ Distance } & \multicolumn{3}{|c|}{ Fertilizer type } & \multirow{2}{*}{$\begin{array}{c}\text { Variety } \\
\times \\
\text { Distance }\end{array}$} & \multirow{2}{*}{$\begin{array}{c}\text { Mean } \\
\text { Variety }\end{array}$} \\
\hline & & Control & Humistar & $\begin{array}{c}\text { Pow } \\
\text { humus }\end{array}$ & & \\
\hline \multirow{2}{*}{$\begin{array}{l}\text { Paris } \\
\text { Island }\end{array}$} & $30 \mathrm{~cm}$ & $1781 \mathrm{~cd}$ & 1872 b-d & $1656 \mathrm{de}$ & $1770 \mathrm{c}$ & \multirow[t]{2}{*}{$1638 \mathrm{~b}$} \\
\hline & $40 \mathrm{~cm}$ & $1601 \mathrm{de}$ & $1344 \mathrm{e}$ & $1576 \mathrm{de}$ & $1507 \mathrm{~d}$ & \\
\hline \multirow[t]{2}{*}{ Binco } & $30 \mathrm{~cm}$ & $2260 \mathrm{ab}$ & $2327 \quad a$ & 2385 a & 2324 a & \multirow[t]{2}{*}{$2176 \mathrm{a}$} \\
\hline & $40 \mathrm{~cm}$ & $\begin{array}{c}2153 \text { a- } \\
c\end{array}$ & 1969 a-d & 1962 a-d & $2028 b$ & \\
\hline \multirow[t]{2}{*}{$\begin{array}{l}\text { Variety } \times \\
\text { Fertilizer }\end{array}$} & $\begin{array}{l}\text { Paris } \\
\text { Island }\end{array}$ & $1691 \mathrm{~b}$ & $1608 \mathrm{~b}$ & $1616 \mathrm{~b}$ & \multirow[t]{2}{*}{$\begin{array}{c}\text { Mean } \\
\text { Distance }\end{array}$} & \\
\hline & Binco & $2207 \mathrm{a}$ & $2148 \quad \mathrm{a}$ & $2174 \quad \mathrm{a}$ & & \\
\hline \multirow{2}{*}{$\begin{array}{c}\text { Distance } \\
\times \\
\text { Fertilizer }\end{array}$} & $30 \mathrm{~cm}$ & $2021 \mathrm{ab}$ & $2099 \mathrm{a}$ & $2021 \mathrm{ab}$ & $2047 \quad \mathrm{a}$ & \\
\hline & $40 \mathrm{~cm}$ & $\begin{array}{c}1877 \text { a- } \\
\text { c }\end{array}$ & $1656 \mathrm{c}$ & $1769 \mathrm{bc}$ & $1767 \mathrm{~b}$ & \\
\hline \multicolumn{2}{|c|}{ Mean Fertilizer } & $1949 \mathrm{a}$ & $1878 \mathrm{a}$ & $1895 \mathrm{a}$ & & \\
\hline
\end{tabular}

The average with same letter for each factor is n.s. according to Duncan's multiple range test under level 0.05 .

Table (12): Effect of variety, plant distance and fertilizer type and their interaction on total yield $\left(\mathrm{kg} .500 \mathrm{~m}^{2}\right)$ of lettuce.

\begin{tabular}{|c|c|c|c|c|c|c|}
\hline \multirow[b]{2}{*}{ Varieties } & \multirow[b]{2}{*}{ Distance } & \multicolumn{3}{|c|}{ Fertilizer type } & \multirow{2}{*}{$\begin{array}{c}\text { Variety } \\
\times \\
\text { Distance }\end{array}$} & \multirow{2}{*}{$\begin{array}{c}\text { Mean } \\
\text { Variety }\end{array}$} \\
\hline & & Control & Humistar & $\begin{array}{l}\text { Pow } \\
\text { humus }\end{array}$ & & \\
\hline \multirow[t]{2}{*}{$\begin{array}{l}\text { Paris } \\
\text { Island }\end{array}$} & $30 \mathrm{~cm}$ & $\begin{array}{c}2346 \text { a- } \\
\text { c }\end{array}$ & 2376 a-c & $2096 \mathrm{~cd}$ & $2273 \mathrm{~b}$ & \multirow[t]{2}{*}{$2050 \mathrm{a}$} \\
\hline & $40 \mathrm{~cm}$ & $1910 \mathrm{de}$ & $1670 \mathrm{e}$ & $1901 \mathrm{de}$ & $1827 \mathrm{c}$ & \\
\hline \multirow[t]{2}{*}{ Binco } & $30 \mathrm{~cm}$ & $2458 \mathrm{ab}$ & $2665 \mathrm{a}$ & $2622 \mathrm{a}$ & $2582 \mathrm{a}$ & \multirow[t]{2}{*}{$2421 \mathrm{a}$} \\
\hline & $40 \mathrm{~cm}$ & $\begin{array}{c}2400 \text { a- } \\
\text { c }\end{array}$ & 2175 b-d & $2205 b-d$ & $2260 \mathrm{~b}$ & \\
\hline \multirow[t]{2}{*}{$\begin{array}{l}\text { Variety } \times \\
\text { Fertilizer }\end{array}$} & $\begin{array}{l}\text { Paris } \\
\text { Island }\end{array}$ & $2128 \mathrm{~b}$ & $2023 \mathrm{~b}$ & $1998 \mathrm{~b}$ & \multirow[t]{2}{*}{$\begin{array}{c}\text { Mean } \\
\text { Distance }\end{array}$} & \\
\hline & Binco & $2429 \mathrm{a}$ & 2420 a & $2413 \mathrm{a}$ & & \\
\hline \multirow{2}{*}{$\begin{array}{c}\text { Distance } \\
\times \\
\text { Fertilizer } \\
\end{array}$} & $30 \mathrm{~cm}$ & $2402 \mathrm{a}$ & $2521 \mathrm{a}$ & $2359 \mathrm{ab}$ & $2427 \mathrm{a}$ & \\
\hline & $40 \mathrm{~cm}$ & $2155 \mathrm{bc}$ & $1922 \mathrm{~d}$ & $2053 \mathrm{~cd}$ & $2043 b$ & \\
\hline \multicolumn{2}{|c|}{ Mean Fertilizer } & $2278 \mathrm{a}$ & 2222 a & 2206 a & & \\
\hline
\end{tabular}

The average with same letter for each factor is n.s. according to Duncan's multiple range test under level 0.05 .

The significant and non-significant increase in vegetative growth characteristics, especially head circumference, leaf area, and stem weight, referred to in Tables (2-6) and cultivated plants at a distance of $40 \mathrm{~cm}$ compared to cultivated plants a distance of $30 \mathrm{~cm}$ is perhaps the most explained reason for moral superiority in the average marketable head. While the significant increase in 
the total and marketable yield and the plants spaced at a $30 \mathrm{~cm}$ on the plants with $40 \mathrm{~cm}$ spacing to an increase in number of heads in plant area unit, which include 16 plants for an experimental unit compared to those planted at a distance of 40 $\mathrm{cm}$, which include 12 plants in the experimental unit, the decline in most vegetative characteristics due to the reduction of planting distances from 40 to $30 \mathrm{~cm}$ did not compensate the increase achieved in the total and marketable yield due to the increase in the number of plants per unit area.

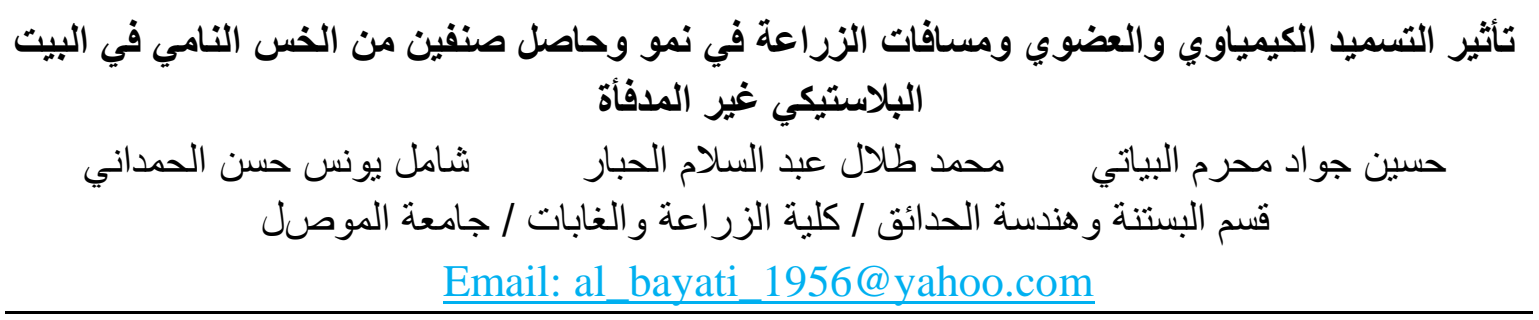

\section{الخلاصة}

نفذت التجربـة في أحد البيوت البلاستيكية الغير مدفأة التابعـة لقسم البستنتة و هندسـة الحدائق / كليـة

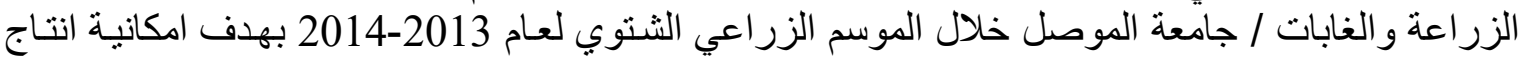

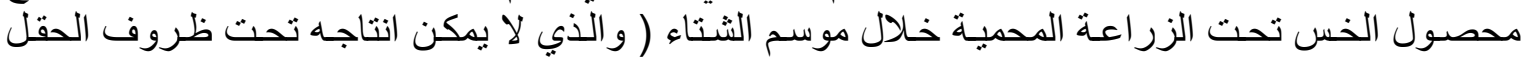

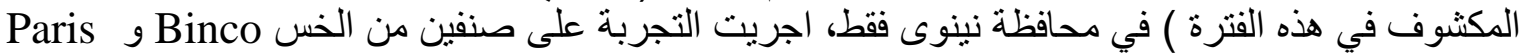
Island

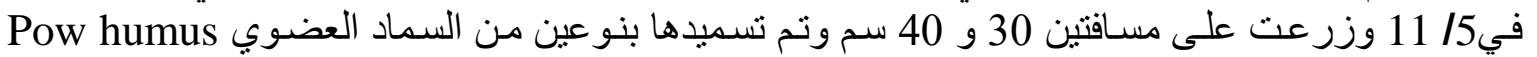

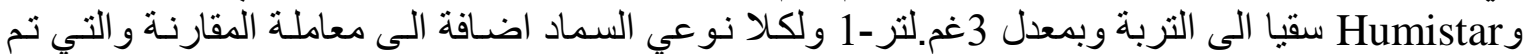

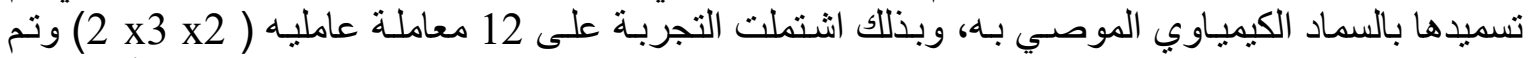

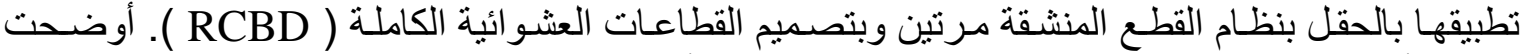

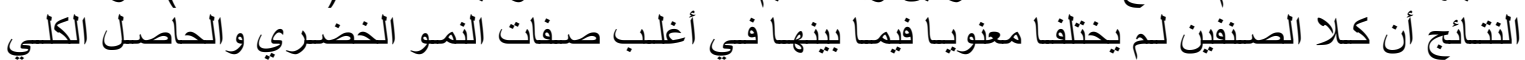

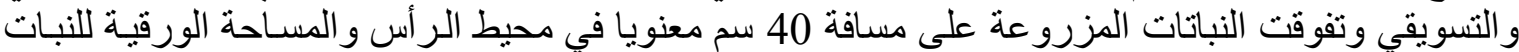

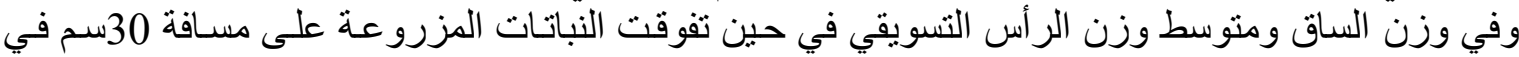

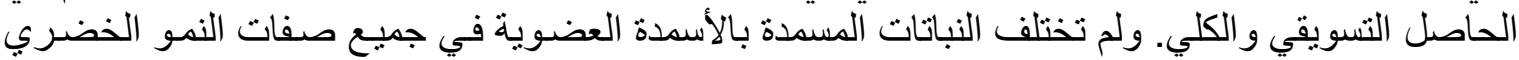
المدروسة باستثناء وزن الساق وفي جميع صفات الحاصل ومكوناتهاته مع النباتات المسمدة بالسماد الكيمياوي.

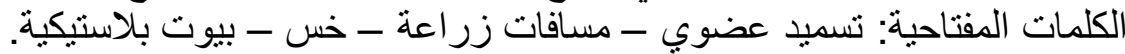

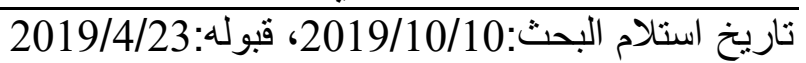

\section{REFERENCES}

Albo-Kalel, Z.K.T. (2018). Effect of Soil Mulching and Organic Fertilizers on Growth and Yield of Lettuce. Thesis of MSC. College of Agriculture, ALQasim Green University, Iraq. (In Arabic).

Al-Habar, M.T.A. and H. J. M .Al-Bayati. (2017). Effect of soil irrigation with two types of sea plant extract and humic acid on growth, quantity and quality of yield in lettuce. Mesopotamia Journal of Agriculture, 45 (2): 81- 88 (In Arabic).

Al-Habar, M.T.A. and M.R.S. Al-Saaberi. (2008). Effect of some agricultural treatments on growth and yield of lettuce Lactuca sativa L. Mesopotamia Journal of Agriculture, 36 (1):

Al-Rawi, K. M. and A. M. Khalaf-Allah. (2000). Design and Analysis of Agricultural Experiments. Foundation of Dar AL-Ktob University of Mosul 
, Ministry of Higher Education and Science Research, Iraq, pp. 488. (In Arabic).

Boroujerdnia, M. and N. A. Ansari. (2007). Effect of different levels of nitrogen fertilizer and cultivars on growth, yield and yield components of romaine lettuce (Lactuca sativa L.). Middle Eastern and Russian Journal of Science and Biotechnology, 1 (2): $47-53$.

Hasan, M. R.; A. K. M. M. Tansin; M. N. Islam; M. A. Ali and J. Uddain . (2017). Growth and yield of lettuce (Lactuca sativa L.) influenced as nitrogen fertilizer and plant spacing. Journal of Agriculture and Veterinary Science, 10 (6): $62-71$.

Khazaei, I.; R. Salehi; A. Kashi and S.M.Mirjalili. (2013). Improvement of lettuce growth and yield with spacing, mulching and organic fertilizer. International Journal of Agriculture and Crop Sciences, 6 (16): 1137 1143.

Matlob, A. N.; E. Sultan and K. S. Abdul. (1989). Vegetable Production. Part 1. Dar AL-Kutub Publication. Mosul University, Iraq. Pp 680. (In Arabic).

Moniruzzaman, M. (2006). Effect of plant spacing and mulching on yield and profitability of lettuce (Lactuca sativa L.), Journal of Agriculture Rural Dev. 4 (1\&2): 107 - 111 .

Ryder, E. J. (1999). Lettuce Endive and Chichory. CABI publishing U.K. pp: 208. Naseri, R.; K. H. Fasihi; A. Hatami and M. M. Poursiahidi. (2010). Effect of planting pattern on yield, yield components, oil and protein content in winter sunflower cv. Sina under rain field condition. Iranian Journal Crop Science, 12: 227-238.

Shahein, M. M.; M. M. Afifi and A. M. Algharib. (2015). Study the effect of humic ubstances on growth, chemical constituents, yield and quality of two lettuce cultivars (c.v.s. Dark Green and Big ell). Journal Mater. Environ. Sciences, 6 (2): $473-486$.

Zink, F. W. and M. Yamaguchi. (1962). Studies on the growth rate and nutrient absorption of head lettuce. Hiligardia 32: 417 - 500. (C. F. Ryder, 1999). 